\title{
A framework for including enhanced exposure to naturally occurring radioactive materials (NORM) in LCA
}

\author{
P. James Joyce ${ }^{1}$ (D) - Andrei Goronovski ${ }^{2}$ - Alan H. Tkaczyk ${ }^{2}$ - Anna Björklund ${ }^{1}$
}

Received: 8 September 2015 / Accepted: 25 October 2016/Published online: 22 November 2016

(C) The Author(s) 2016. This article is published with open access at Springerlink.com

\begin{abstract}
Purpose Despite advances in the development of impact categories for ionising radiation, the focus on artificial radionuclides produced in the nuclear fuel cycle means that the potential impacts resulting from increased exposure to naturally occurring radioactive materials (NORM) are still only covered to a limited degree in life cycle assessment (LCA). Here, we present a potential framework for the inclusion of the exposure routes and impact pathways particular to NORM in LCA. Methods We assess the potential magnitude of enhanced NORM exposure, particularly in light of the potential use of NORM residues in building materials, and set out the potential exposure routes that may exist. We then assess the current state of the art, in terms of available fate, exposure and damage models, both within and outside of the LCA sphere. Finally, these exposure routes and modelling techniques are combined in order to lay out a potential framework for NORM assessment in LCA, both in terms of impact on humans and ecosystems.

Results and discussion Increased exposure to NORM radionuclides can result either from their release to the environment or their proximity to humans as they reside in stockpiles, landfills or products. The exposure route via products is considered to be increasingly significant in light of current attempts
\end{abstract}

Responsible editor: Roland Hischier

P. James Joyce

pjjoyce@kth.se

1 Department of Sustainable Development, Environmental Science and Engineering (SEED), Royal Institute of Technology (KTH), 100 44 Stockholm, Sweden

2 Institute of Physics, University of Tartu, Ravila 14c, 50411 Tartu, Estonia to incorporate technologically enhanced NORMs (TENORM) including bauxite residue into building materials, by groups such as the ETN-MSCA REDMUD project. Impact assessment models for NORM exposure are therefore required to avoid potential burden shifting in the assessment of such TENORM products. Models describing the fate of environmental releases, the exhalation of radon from building products and the shielding effects on landfills/stockpiles are required to assess potential exposure. Subsequently, models relating exposure to radiation sources and the effective internal and external dose received by receptors are required. Finally, an assessment of the damage caused to the receptors is desirable.

Conclusions A sufficient suite of currently existing and internationally recognised models exist that can, with varying degrees of modification, form the building blocks of a comprehensive NORM characterisation method for LCA. The challenge ahead lies in consolidating these models, from disparate fields, into a coherent and generally applicable method for the assessment of enhanced NORM exposure in LCA.

Keywords Ionising radiation - LCIA · Naturally occurring radioactive material $\cdot$ NORM $\cdot$ TENORM $\cdot$ Impact assessment model

\section{Introduction}

Prolonged exposure to low-dose ionising radiation is associated with adverse health effects in both humans and nonhuman biota (IAEA 1976; ICRP 2007). Natural sources of radiation, including radiation from building materials, are by far the most significant source of ionising radiation humans and ecosystems are subjected to, estimated at $2.4 \mathrm{mSv}^{-1}$ per person, accounting for $80 \%$ of the worldwide annual per 
capita effective dose (UNSCEAR 2008), as presented in Fig. 1. By way of comparison, routine releases from the nuclear fuel cycle account for less than $0.01 \%$ of annual per capita effective dose $\left(0.2 \mu \mathrm{Sv} \mathrm{a}^{-1}\right)$ (UNSCEAR 2000). Over $80 \%$ of natural radiation results from the decay chains of radioactive isotopes with half-lives comparable to the age of the earth, so-called primordial isotopes, contained within minerals in the earth's crust. ${ }^{1}$ Where human activities have increased the potential for exposure to materials containing these radioactive elements, these materials are classed as naturally occurring radioactive materials (NORM). Increased exposure to NORM has the potential to lead to adverse health effects upon these receptors (UNSCEAR 2000). The two most important naturally occurring isotopes from a radioprotection standpoint are ${ }^{238} \mathrm{U}$ and ${ }^{232} \mathrm{Th}$ (and their decay series), with ${ }^{40} \mathrm{~K}$ also representing a significant source of terrestrial radioactivity (World Nuclear Association 2014).

Many existing industrial processes have been identified as potential sources of NORM exposure (European Union 2014, Annex VI; World Nuclear Association 2014); however, one potentially significant emerging source of NORM exposure is the valorisation of bauxite residue (BR), the current focus of the MSCA-ETN REDMUD project (MSCA-ETN REDMUD 2015). Bauxite is the main ore used in the production of aluminium (Aluminium Leader 2015) and contains $0.4-0.6 \mathrm{kBq} /$ $\mathrm{kg}$ of ${ }^{238} \mathrm{U}$-series radionuclides and $0.3-0.4 \mathrm{kBq} / \mathrm{kg}$ of ${ }^{232} \mathrm{Th}$ series radionuclides (UNSCEAR 2000). When alumina $\left(\mathrm{Al}_{2} \mathrm{O}_{3}\right)$ is extracted from the bauxite via the Bayer process, these nuclides, along with a number of rare earth metals (including scandium) and a number of iron and aluminium oxides, are concentrated in the residue from the process, known as bauxite residue, or red mud. In Australian bauxites, the activity of ${ }^{238} \mathrm{U}$ and ${ }^{232} \mathrm{Th}$ decay chains has been recorded as 1.6 to 2.9 times and 2.4 to 3.0 times higher than the parent ore respectively (O'Connor et al. 2013). Such materials, containing artificially elevated concentrations of NORM radionuclides, are referred to as technologically enhanced NORM (TENORM). Further extraction of useful materials, such as iron and scandium, from BR has the potential to lead to the release of radionuclides to the environment via routine process emissions. In addition, NORM radionuclides are likely to be further concentrated in the resulting residues. As part of its 'zero-waste' aspiration, the MSCA-ETN REDMUD project aims to use these TENORM residues in products such as geopolymers and/or building products (MSCA-ETN REDMUD 2015).

The radiological impacts of the NORM in the valorisation of BR are likely to manifest themselves at a place and a time other than that of their original processing, that is, at another

\footnotetext{
${ }^{1}$ The remainder of natural radiation exposure is of cosmogenic nature (i.e. from cosmic rays and as a result of neutron production in the upper atmosphere).
}

stage in their life cycle. A life cycle perspective is therefore important in order to avoid burden shifting and environmental sub-optimisation in the development of valorisation technologies. Life cycle assessment (LCA) is a standardised and internationally recognised method to quantify and assess the whole life cycle impact of products and services across a variety of potential impact categories. The aim is to gain a holistic view of the potential effects of the human actions leading to the provision of these products.

In this article, we investigate how the potential adverse effects resulting from increased exposure to NORM could be comprehensively incorporated into LCA, in a way that would allow the assessment of relevant life cycle environmental and health impacts of products and processes where NORM exposure is likely or significant.

Specifically, we aim to:

- Establish whether the development of impact assessment models for NORM exposure is warranted, particularly in the context of $\mathrm{BR}$ valorisation

- Assess the existing literature to estimate how and where significant release of and exposure to NORM might occur, using BR valorisation as an example (in order to be able to focus LCA modelling efforts on relevant issues)

- Compile a representative list of existing release, fate, exposure and impact models from current literature and evaluate how appropriate they are for the integration of NORM into LCA

- Outline a suitable framework for the incorporation of NORM into LCA, determine the suitability of the existing models in the context of this framework and identify gaps where they exist

\section{Methods}

\subsection{Justification of impact assessment model development}

As a first stage, currently existing life cycle impact assessment models for ionising radiation (Frischknecht and Braunschweig 2000; Garnier-Laplace et al. 2009) were assessed to establish whether the potential impacts of NORM are already accounted for to a sufficient degree within the LCA framework.

Cucurachi et al. (2014) propose a generalised framework for the inclusion of emerging impacts in LCA. The Cucurachi et al. framework divides the development of an impact category into two domains, the specialist domain, which sets out the technical evidence to justify the development of the impact category, and the LCA domain, in which the specialist knowledge is applied in the LCA context. As such, the specialist domain acts as a set of prerequisite criteria for impact category 
Fig. 1 Worldwide average annual human exposure to ionising radiation (UNSCEAR 2008)
Natural sources : $80 \%$

Artificial sources: $20 \%$

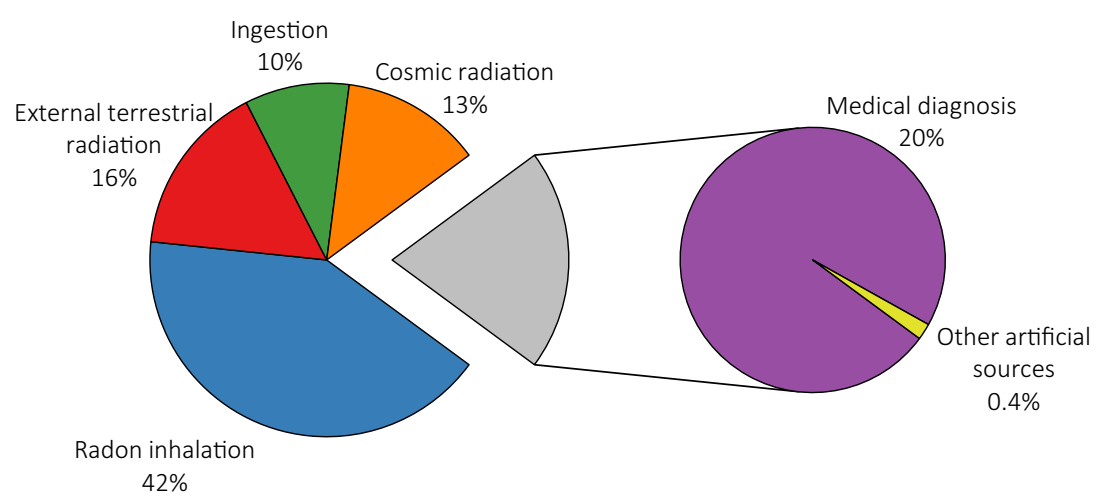

development. In order to establish whether the development of a new, separate impact model for NORM is justified, we assessed NORM impact against these specialist domain criteria. The criteria are listed in full in Table 2.

\subsection{Identification of release and exposure pathways}

In order to understand the potential releases and exposure pathways relevant to NORM, representative literature covering radiological exposure and toxicological risk was reviewed and evaluated. Potential pathways were considered in the context of NORM processing, using the life cycle of BR valorisation as an example where relevant. This includes the processing stage, use stage (incorporation into building materials) and disposal (in landfill). Both humans and non-human organisms (terrestrial and aquatic) were considered as potential receptors. A cause and effect chain between inventoriable flows relating to NORM radionuclides and potential impact on these receptors was established.

\subsection{Model identification and assessment}

Once the potentially relevant pathways of exposure were identified, relevant academic and specialist literature was reviewed in order to identify candidate models which had the potential to be used or adapted to represent the cause-effect chain for each exposure pathway identified. Models already used in LCA, both within ionising radiation and toxicological impact categories, were considered first. Following this, broader literature searches for compartmental models, multimedia models, fate models, exposure models and damage models were conducted, with a focus on the radiological literature.

It was anticipated that the existing models were likely to be limited by the lack of parameters for the NORM isotopes and/ or the diversity of life forms that are exposed. In these cases, the potential of the models to be extended to include these missing elements was considered.
A systematic review of each of the candidate models identified was carried out according to the criteria set out in Table 1. The criteria are adapted from the review criteria used in the International Reference Life Cycle Data System (ILCD) review of life cycle impact assessment methods carried out on behalf of the EU JRC (Hauschild et al. 2013).

\subsection{Framework development}

The results of the exposure pathway/cause-effect analysis and the model review were combined to develop a clear framework for a NORM impact model, following the direction of Cucurachi et al. (2014).

\section{Results}

\subsection{Justification of impact assessment model development}

Ionising radiation impact categories are currently available in commonly used LCA software (SimaPro (Pre Sustainability 2014), GaBi (Thinkstep 2014)) both for human health (Frischknecht and Braunschweig 2000) and ecosystems (Garnier-Laplace et al. 2009). Both impact categories are recommended (at least as an interim choice) in the ILCD guidelines for assessing ionising radiation at a midpoint level (European Commission 2011). These impact categories were developed to assess the potential impact of operational releases of (mainly) artificial radionuclides from the nuclear fuel cycle for power generation. As a result, none of the three main NORM radioisotopes are characterised in the ecosystem impact category, while only releases of ${ }^{238} \mathrm{U}$ to air and water are characterised in the human impact category. Additionally, exposure routes associated with NORM incorporated into building materials, both direct exposure to gamma radiation and through the exhalation of radon into interior spaces, are not modelled in either characterisation method, and therefore, these impacts are not characterised in either category. While 
Table 1 Criteria for model review

\begin{tabular}{ll}
\hline Item & Description \\
\hline $\begin{array}{l}\text { Completeness of scope } \\
\text { How well does the model cover the environmental and/or exposure mechanisms } \\
\text { associated with NORM exposure? } \\
\text { To what extent are the critical parts of the impact pathway included and modelled } \\
\text { in accordance with the current state of the art? }\end{array}$ \\
$\begin{array}{c}\text { Robustness and } \\
\text { certainty }\end{array}$ \\
$\begin{array}{c}\text { How well has the model been peer reviewed? Can it be validated against monitoring } \\
\text { data, and are uncertainties reported? }\end{array}$ \\
$\begin{array}{c}\text { Transparency and } \\
\text { reproducibility }\end{array}$ \\
$\begin{array}{c}\text { How applicable is the model to NORM/LCA? Does it require any modification to be } \\
\text { acceptance }\end{array}$ \\
and the applied input data?
\end{tabular}

these exposure routes are highly unlikely to occur as part of the nuclear fuel cycle, they are a potentially important source of exposure for BR valorisation, as well as the utilisation of other NORM-containing materials.

A method to account for indoor exposure to radiation (in addition to organic chemicals) from residential building materials in LCA has been proposed by Meijer et al. (2005a; 2005b). To date, however, none of the published case studies citing this method mention radiation and rather focus on the organic chemical aspect of the method (Kikuchi and Hirao 2010; Walser et al. 2014). This method is discussed in detail below.

Table 2 summarises the suitability of developing a NORM exposure impact category according to the framework set out by Cucurachi et al. (2014).

\subsection{Identification of release and exposure pathways}

NORM utilisation has the potential to expose human and nonhuman biota to additional radiation. The cause-effect chains for these additional exposures take the form of a sourcepathway-receptor relationship (Holdgate 1980). In the case of NORM, we can broadly define two main source typesdirect emissions of radionuclides to the environment and radionuclides contained within TENORMs. Each of these sources has different pathways to the receptors. These pathways are summarised in Fig. 2.

When NORM radionuclides are released as emissions to air and water, they are subsequently dispersed and transported through the environment and, via various mechanisms (e.g. deposition, translocation, ingestion and bioaccumulation (IAEA 2010)), can end up in proximity to human and nonhuman biota, resulting in exposure to ionising radiation. Emissions of nuclides to air via stack emissions may be directly inhaled by humans and animals. In addition, these nuclides may be deposited onto crops and/or forage and enter the food chain resulting in exposure via ingestion. Airborne emissions may also be deposited to water bodies, leading both to the exposure of aquatic organisms and the potential to enter the food chain via aquatic sources and/or direct ingestion by humans and animals. Direct emissions to water from NORM processing have similar potential pathways to receptors. The environmental fate of these radionuclides can be mathematically modelled.

Humans can be exposed to radionuclides in NORM as a result of their prolonged proximity to these materials. The most likely source of prolonged exposure to TENORM, especially that produced by BR valorisation, is through its incorporation in building materials; this is an area of increasing interest in the reuse of industrial waste materials (Batayneh et al. 2007; Raut et al. 2011). Many hazardous substances in the wastes are effectively immobilised in the upcycled products (Van Jaarsveld et al. 1997), preventing their release into indoor environments. However, the decay potential of the radionuclides within these products is not affected and, for walls less than $30 \mathrm{~cm}$ thick, self-shielding of gamma radiation is not significant (Koblinger 1984; Meijer et al. 2005a). Most domestic applications do not require wall thicknesses over $30 \mathrm{~cm}$ (e.g. 19-29 cm dependent on wall height in UK building regulations (HM Government 2013)), and as a result, these products are likely to emit gamma radiation and radon into the indoor environment. Standard building materials will of course also contain certain levels of naturally occurring radionuclides, which will vary by geography (Trevisi et al. 2012). The incorporation of NORM-enriched wastes into building material has the potential to lead to exposure above that of the average building material.

In addition to the external gamma dose, radiological exposure from building materials can occur via the inhalation of radon $\left({ }^{222} \mathrm{Rn}\right)$ and its daughter nuclides. ${ }^{222} \mathrm{Rn}$ is a radioactive noble gas produced in the decay chain of ${ }^{238} \mathrm{U}$ in the building materials which can subsequently be released from the materials into living spaces. The 'fate' of gamma-emitting radionuclide decay chains is defined by their presence in the material. ${ }^{238} \mathrm{U},{ }^{232} \mathrm{Th}$ and ${ }^{40} \mathrm{~K}$ are effectively immobilised for the 
Table 2 Relevance of NORM with respect to the criteria of Cucurachi et al. (2014) time in which the materials are in use, and therefore, the exposure of the receptor to gamma radiation released by their respective decay chains is not dependent on the physical fate
Sufficient, uncontested evidence of a mechanistic link between causes and effects of exposure and impact, which has been confirmed in a sufficient number of instances

There is a standard for the quantification of the impacts of the stressor under study, along with one or more standard models for the quantification of the impact which has been corroborated in a sufficient number of instances

An international agency has quantified the importance of the impact. The results suggest that the issue is important compared to others already present in LCA.

Trends suggest that the size of the impact will grow with the diffusion of certain technologies or products.

It is necessary to quantify the impact across the life cycle because impacts are associated to a product system and to different stages of a global life cycle.

A sufficient body of information allows for the study of the impact in relationship with a specific area of protection.
Relevance of NORM

The disintegration of NORM isotopes and daughter isotopes in their decay chain release ionising radiation, primarily in the form of gamma rays, which have been demonstrated to have adverse impacts on both humans and ecosystems in innumerable cases.

Standard measurements and units for radioactive activity $(\mathrm{Bq})$, radiation dose (Gy) and effective dose (Sv) exist. Additionally, dose-response relationships, establishing adverse effects of radiation doses, have been derived for humans and a variety of non-human biota.

The United Nations Scientific Committee on the Effects of Atomic Radiation (UNSCEAR) estimates that over $85 \%$ of global per capita radiation dose is from NORM, compared with less than $0.01 \%$ from operational releases of artificial nuclides in the nuclear fuel cycle. The impact of the latter is already present in LCA.

Increasing use of NORM-containing materials and residues, particularly in $\mathrm{BR}$ valorisation, is likely to increase exposure to NORM.

Exposure to NORM occurs at multiple stages within the life cycle of NORM containing materials, including, but not limited to, processing, use and waste treatment.

Sufficient information exists to study the impact of ionising radiation on human health and the health of representative non-human organisms (as a proxy for ecosystems).

Fig. 2 Potential exposure pathways to NORM radionuclides as a result of NORM processing

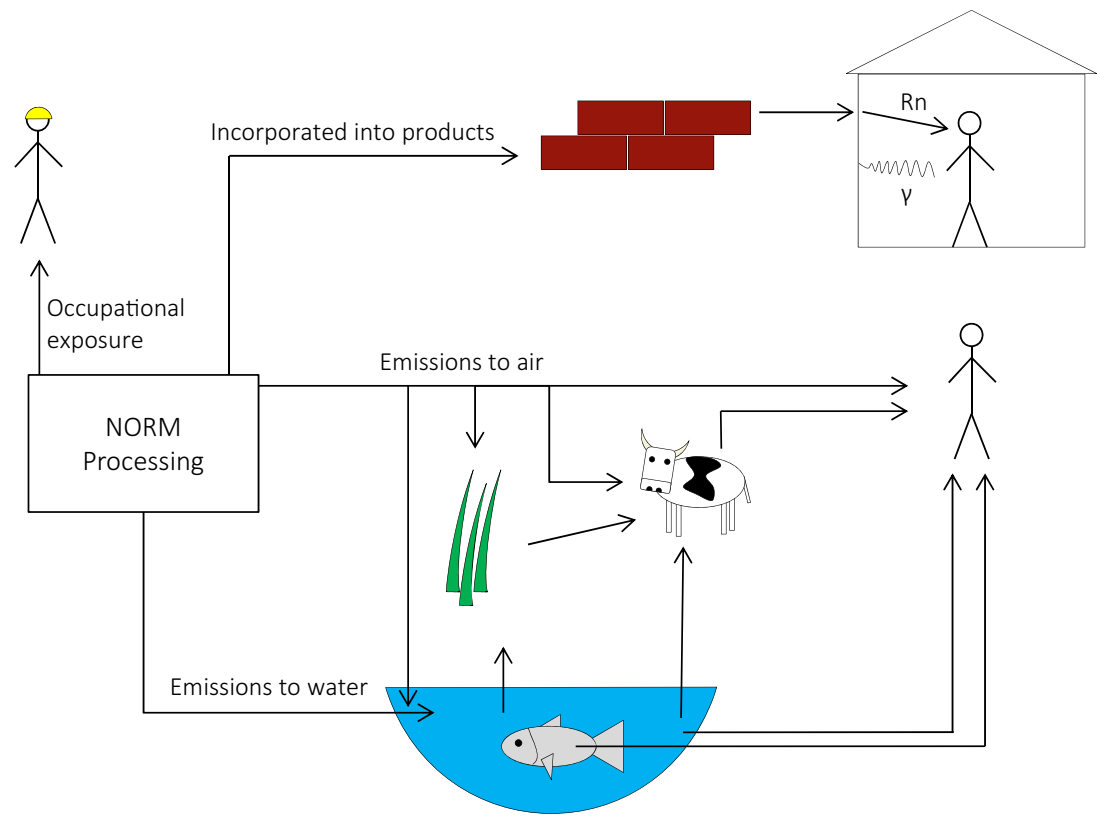


report (UNSCEAR 2000), which shows that uranium and thorium decay products (other than radon) make only a minor contribution to indoor exposure due to inhalation. Both the exposure to gamma radiation and release and subsequent inhalation of ${ }^{222} \mathrm{Rn}$ can be mathematically modelled.

Humans may also come into prolonged proximity to NORM radionuclides during its processing and disposal. Stockpiles of ores and/or residues (including BR prevalorisation) as well as storage of final TENORM products and residues (including landfilling of TENORM waste) present potential sources of occupational exposure.

Additional human radiation exposure as a result of environmental releases of NORM during processing is highly dependent on the material and the process. UNSCEAR (2000) has estimated that for industries posing the greatest exposure risk, increased localised doses are in the order of 1$10 \mu \mathrm{Sv} \mathrm{a}^{-1}$, with some groups potentially receiving doses up to $100 \mu \mathrm{Sv} \mathrm{a}^{-1}$. Occupational exposures from ore stockpiles are estimated to be up to $300 \mu \mathrm{Sv} \mathrm{a}^{-1}$, again depending on the activity of the material.

Releases of NORM nuclides to the environment, for example from electricity production and phosphate mining, while inventoried in current LCI data, are not characterised by the current ionising radiation impact methods. The existence of such uncharacterised nuclides has been highlighted by the ILCD (European Commission 2010) and the addition of further nuclides highlighted as a high-priority research need in this area.

The presence of NORM in building materials has the potential to have a far more significant effect on increasing radiation exposure at the use phase than emissions of NORM nuclides to the environment at other stages of the life cycle. Table 3 shows the typical primordial nuclide content of bricks, cement, concrete and bauxite residue, as well as the corresponding activity concentration index $(I) . I$ is calculated according to the formula set out in the EU Basic Safety Standards Directive (European Union 2014) as follows:

$I=\frac{C_{\mathrm{Ra} 226}}{300 \mathrm{~Bq} / \mathrm{kg}}+\frac{C_{\mathrm{Th} 232}}{200 \mathrm{~Bq} / \mathrm{kg}}+\frac{C_{\mathrm{K} 40}}{3000 \mathrm{~Bq} / \mathrm{kg}}$

where $\mathrm{C}_{\mathrm{Ra} 226}, \mathrm{C}_{\mathrm{Th} 232}$ and $\mathrm{C}_{\mathrm{K} 40}$ are the activity concentration of the corresponding radionuclides in a material measured in becquerels per kilogram. ${ }^{226} \mathrm{Ra}$ and its decay products are the most important part of the ${ }^{238} \mathrm{U}$ decay chain from a radiological point of view, which is why it is used in the calculation of $I$ instead of ${ }^{238} \mathrm{U}$ (Markkanen 1995). At secular equilibrium, the activity concentration of ${ }^{238} \mathrm{U}$ is identical to that of ${ }^{226} \mathrm{Ra}$ in any case. A value of $I$ greater than 1 indicates that the material may result in doses exceeding the reference level for indoor external gamma exposure of $1 \mathrm{mSv}$ per year (above outdoor exposure) in Article 75(1) of the EU Basic Safety Standards Directive, and by the International Commission on Radiological Protection (ICRP 2007), above which there is a risk of adverse effects. Values of $I$ for pure bauxite residue are greater than 1 .

This is borne out by experimental data. Dose equivalents for experimental buildings built in Jamaica using bricks containing local bauxite residue were estimated to be 1.44 and $2.07 \mathrm{mSv}$ per annum for bricks made from 50 and $100 \%$ bauxite residue respectively, an increase of 0.58 and $1.21 \mathrm{mSv}$ over standard concrete (McLeod 1998). It is worth noting that these increased doses are from building materials using unprocessed bauxite residue. The MSCA-ETN REDMUD project aims to extract useful materials from bauxite residue prior to its use in building materials, with the potential to further concentrate NORM in the resulting residue.

The impacts of such exposure are non-trivial. The increase in fatal cases and non-fatal cases of cancer per $1 \mathrm{man} / \mathrm{Sv}$ excessive exposure (collective dose) is estimated to be 0.05 and 0.12, respectively, by Frischknecht and Braunschweig (2000), with UNSCEAR (2000) estimating an increase of fatal cancer cases of 0.08 for males and 0.11 for females (corresponding to 0.096 per average person assuming equal gender distribution). The latter provides higher risk of exposureinduced death, since it does not include any reduction factors for low dose rates, which are the case for natural radioactivity.

The $I$ index provides a threshold value for radionuclide concentration within construction material, and is indicative of its legislative importance; however, it does not provide any indication of the long-term damage to inhabitants of such a building in comparison to other impacts. In order to assess this, albeit at a coarse level, we can look at published doses to general public from NORM materials. One such example is application of fly ash in building materials as presented in Table 4. Considering a lifetime period of 75 years and three inhabitants on average per

Table 3 Representative activity concentration of building materials and bauxite residue (BR)

\begin{tabular}{|c|c|c|c|c|c|}
\hline Material & ${ }^{226} \mathrm{Ra}\left({ }^{238} \mathrm{U}\right) \mathrm{Bq} \mathrm{kg}{ }^{-1}$ & ${ }^{232} \mathrm{Th} \mathrm{Bq} \mathrm{kg}^{-1}$ & ${ }^{40} \mathrm{~K} \mathrm{~Bq} \mathrm{~kg}^{-1}$ & I & Source \\
\hline Brick (EU average) & 47 & 48 & 598 & 0.6 & Trevisi et al. 2012 \\
\hline Concrete (EU average) & 60 & 35 & 392 & 0.5 & Trevisi et al. 2012 \\
\hline Cement (EU average) & 45 & 31 & 216 & 0.4 & Trevisi et al. 2012 \\
\hline BR (global average) & 337 & 480 & 205 & 3.6 & Nuccetelli et al. 2015 \\
\hline BR (Greece) & 230 & 387 & 17 & 2.7 & Own measurements \\
\hline
\end{tabular}


Table 4 Doses to inhabitants due to fly ash utilisation in construction materials in the UK (UNSCEAR 2008)

\begin{tabular}{lll}
\hline NORM application & Exposure route & Annual dose (mSv) \\
\hline Building material from ash & Radon inhalation & 0.6 \\
& External exposure & 0.9 \\
\hline
\end{tabular}

house, we convert the annual dose to damage using the dose to damage coefficient of Frischknecht and Braunschweig (2000) (Hierarchical/Egalitarian scenario; 1.51 disability adjusted life years (DALY)/man.Sv) and get 0.510 DALYs per house per lifetime. Comparing this obtained value to the total production impacts of the major building materials present in the reference dwelling used by Meijer et al. (2005b) (Table 5), it is clear that damage from the ionising radiation during the use phase has the potential to be the dominant human health impact in the life cycle of construction materials and is an issue worthy of consideration. This is true both when considering only those endpoint models recommended by ILCD and when considering all human health endpoint models in ReCiPe (Goedkoop et al. 2009).

The use phase human health impact of NORM materials can be also compared to the use phase impacts resulting from the power consumption of the inhabitants over the same period. The annual energy consumption in the UK per household is $3941 \mathrm{kWh}$ (World Energy Council 2016; 2014 data), which equals $1.06 \mathrm{TJ}$ of energy assuming same power consumption over 75 years. Applying the damage coefficient from Frischknecht and Braunschweig (2000) for the average UCTEP power plant (0.061 DALY/TJ considering effects of ionising radiation, chemical toxicity and respiratory effects) would give 0.06466 DALY per household per 75 years, which is almost an order of magnitude lower than possible use phase damage from construction materials calculated above.

For biota exposure, the initially accepted approach, that safety measures sufficient to protect humans are also sufficient to protect wildlife (ICRP 1977), has been reconsidered in more recent years, on the basis that species sensitivity and exposure pathways to ionising radiation might differ from those of humans. As discussed in the PROTECT report (Andersson et al. 2008), there is no international consensus on the threshold values for environmental protection (proposed limiting exposure dose rates differ in the range of 10$400 \mu \mathrm{Gy} \mathrm{h}{ }^{-1}$, with some authors providing limiting radionuclide concentrations instead); however, there is an agreement that separate investigations into the radiological exposure of biota should be performed.

\subsection{Inventory assessment}

For each of the pathways outlined above, inventory data is required, either for releases of NORM radionuclides to the environment or for their activity concentration in materials.
At the production stage, inventory data for the release of NORM radionuclides to air are available in many existing processes in the Ecoinvent database for which NORM may be significant, including electricity production from hard coal and lignite $\left({ }^{232} \mathrm{Th},{ }^{238} \mathrm{U}\right.$ and $\left.{ }^{40} \mathrm{~K}\right)$ and phosphate production $\left({ }^{232} \mathrm{Th}\right.$ and $\left.{ }^{238} \mathrm{U}\right)$. For novel processes, emissions may be estimated via mass balance (activity concentration in productactivity concentration in input material(s)), combined with reasonable assumptions regarding emission pathways.

At the use stage, activity concentrations in common building materials and residues are available in the scientific literature (Meijer et al. 2005b; Trevisi et al. 2012; Nuccetelli et al. 2015), which may be combined to estimate activity concentrations of mixtures. For truly novel applications, however, gamma spectroscopy measurements of the materials produced are likely to be required.

The Ecoinvent models for landfill emissions do not include NORM elements (with the exception of potassium and lead) (Doka and Hischier 2005; Doka 2009). In the absence of initial concentration data for landfills and their leachate for these elements, approximations will need to be made. TENORM material is most likely to occur as industrial waste and therefore be disposed of in residual material landfill. With the single exception of chromium, the total mobilisable fraction $\left(\mathrm{TK}_{\infty}\right)$ for all elements in the residual landfill model is assumed to be 1 (i.e. 100\%) (Doka 2009, Table A.8, pp. 120). Given that no data is available, we suggest that for the missing radionuclides the long-term transfer coefficient $\left(\mathrm{TK}_{0-60,000}\right)$ be set to $\mathrm{TK}_{\infty}$ (i.e. 1).

For elements that are not easily soluble, ${ }^{2}$ a constant leachate concentration is assumed (ibid, pp. 25). Given that residual material landfills are assumed to remain in the carbonate (acid buffering) phase for more than 60,000 years (ibid. pp. 70), this constant leachate concentration is maintained in both the short and long terms. In the original model, the assumption of constant leachate concentration is used to approximate $\mathrm{TK}_{0-60,000}$ from the short-term transfer coefficient $\left(\mathrm{TK}_{0-100}\right)$ (ibid, Eq. 5.12, pp. 29). In this case, however, we propose the reverse, to approximate $\mathrm{TK}_{0-100}$ from the assumed value of $\mathrm{TK}_{0-60,000}=\mathrm{TK}_{\infty}=1$. This gives a short-term transfer coefficient of $\mathrm{TK}_{0-100}=0.0017$.

This translates to the release of $0.17 \%$ of the total mass of the radionuclide over the first 100 years (short-term emissions) and $99.83 \%$ over years 100-60,000 (long-term emissions). If long-term emissions are to be excluded in a given analysis, the sensitivity of the results to the assumed proportions of short- and long-term emissions from landfill should be analysed.

\footnotetext{
${ }^{2}$ Easily soluble elements are defined in Doka (2009) as 'the monovalent ions $(\mathrm{Na}+, \mathrm{K}+, \mathrm{Cl}-, \mathrm{F}-, \mathrm{Br}-, \mathrm{I}-)$, oxianion-forming elements $\left(\mathrm{WO}_{4}^{2-}, \mathrm{HVO}_{4}{ }^{2-}\right.$, $\left.\mathrm{Cr}^{(\mathrm{VI})} \mathrm{O}_{4}{ }^{2-}, \mathrm{MoO}_{4}{ }^{2-}, \mathrm{HBO}_{3}{ }^{2-}, \mathrm{HSeO}_{4}{ }^{-}, \mathrm{SbO}_{4}{ }^{3-}, \mathrm{HAsO}_{4}{ }^{2-}\right)$ and also nitrogen (as nitrate $\mathrm{NO}^{3-}$ )'.
} 
Table 5 Human health impact (ReCiPe v1.12 Hierarchical approach) of production of major building materials in reference dwelling (Meijer et al. 2005b) (DALY)

\begin{tabular}{|c|c|c|c|c|c|c|c|}
\hline \multirow[t]{3}{*}{ Impact category } & \multirow[t]{3}{*}{ Total impact (DALY) } & \multicolumn{6}{|c|}{ Contribution from } \\
\hline & & \multicolumn{3}{|c|}{ ILCD recommended } & \multicolumn{3}{|c|}{ ILCD interim } \\
\hline & & Human toxicity & $\begin{array}{l}\text { Photochemical } \\
\text { oxidant formation }\end{array}$ & $\begin{array}{l}\text { Particulate matter } \\
\text { formation }\end{array}$ & $\begin{array}{l}\text { Climate } \\
\text { change }\end{array}$ & $\begin{array}{l}\text { Ozone } \\
\text { depletion }\end{array}$ & $\begin{array}{l}\text { Ionising } \\
\text { radiation }\end{array}$ \\
\hline Clay brick & 0.0036 & $6.4 \%$ & $0.01 \%$ & $19.7 \%$ & $73.8 \%$ & $0.01 \%$ & $0.04 \%$ \\
\hline Sand-lime brick & 0.0145 & $7.1 \%$ & $0.01 \%$ & $20.7 \%$ & $72.1 \%$ & $0.01 \%$ & $0.04 \%$ \\
\hline Concrete block & 0.0181 & $10.6 \%$ & $0.01 \%$ & $21.8 \%$ & $67.4 \%$ & $0.01 \%$ & $0.1 \%$ \\
\hline Total & 0.0362 & $8.8 \%$ & $0.01 \%$ & $21.2 \%$ & $70.0 \%$ & $0.01 \%$ & $0.1 \%$ \\
\hline Total (ILCD recommended) & 0.0108 & $29.39 \%$ & $0.02 \%$ & $70.59 \%$ & & & \\
\hline
\end{tabular}

(1) $6200 \mathrm{~kg}$ - market for clay brick (global) (Ecoinvent 2015a), (2) 40,900 kg — market for sand-lime brick (global) (Ecoinvent 2015b), (3) 91,800 kgmarket for concrete block (global) (Ecoinvent 2015c)

\subsection{Model identification and assessment}

The modelling required to establish the cause-effect relationship between sources of NORM, the exposure received by receptors and the potential damage caused by this exposure can be subdivided into three stages, fate, exposure and damage.

Fate models deal with the physical movement of the radionuclides from their point of release to their point of exposure. The input to a fate model is activity (measured in $\mathrm{Bq}$ ) of a given radionuclide in the environmental compartment it is released to. The output, also measured in becquerels, is the calculated activity of that radionuclide in the compartment in which the receptor is found.

Exposure models deal with the relationship between the presence of a source of exposure near to or within a receptor and the amount of potentially damaging radiation received. The input to exposure models is the activity of a radionuclide (measured in $\mathrm{Bq}$ ), and the output is the dose received by the receptor. Dose is measured in two ways. The absorbed dose, measured in SI units of grays (Gy), reflects the amount of incident radiation energy absorbed by a receptor. Not all tissue is equally susceptible to radiation damage; therefore, to reflect the stochastic health risk of exposure to radiation, the absorbed dose is converted to an effective dose, measured in SI unit of sieverts ( $\mathrm{Sv}$ ), accounting for the potential damage inflicted by radiation exposure.

Finally, damage models deal with the subsequent effects on the health or viability of a human or ecosystem receiving the given dose of radiation. The inputs to damage models are the dose (in Sv). The output is dependent on the model and the receptor.

Nine models were identified as potential candidates for the incorporation of NORM in LCA, four of which have been implemented in LCA. These models cover the fate, exposure and damage elements of the cause-effect pathway and are shown in Table 6.

The results of the model review are summarised in Table 7. Descriptions of the models are given below.

\subsubsection{Frischknecht and Braunschweig (2000)}

The Frischknecht and Braunschweig (hereafter F \& B) model was developed in order to assess the ionising radiation impacts associated with the nuclear fuel cycle in an LCA context. The fate modelling used is detailed and specific to elements of the French nuclear fuel cycle, including factors concerning the surroundings of the sites in question (population distribution etc.). The model is based on the ExternE model and is a generalised case of the modelling described in Dreicer et al. (1995). For atmospheric modelling, a Gaussian plume model is used. For liquid releases into rivers, a simple box model is used, dividing the river into several sections and assuming instantaneous mixing in each section. For liquid discharges into the sea, a model of the European sea is used (including the northern European waters and the Mediterranean Sea). As the model accounts for population distribution, the release to each medium is related directly to the collective received dose, effectively combining the fate and exposure models into a single step. Exposure is measured in man.Sv (representing the total collective dose distributed among the affected population). Damage analysis is performed in the F \& B model, using the concept of disability adjusted life years (DALY) as the damage criterion, based on epidemiological data.

The F \& B model includes exposure and damage factors for the release of ${ }^{238} \mathrm{U}$ but does not include data for ${ }^{232} \mathrm{Th}$ or ${ }^{40} \mathrm{~K}$. Although the model is well documented in the Dreicer report, the model is sufficiently complex and opaque to make the 
Table 6 Models identified for review

\begin{tabular}{|c|c|c|c|}
\hline & Fate & Exposure & Damage \\
\hline \multirow[t]{4}{*}{ LCA models } & Frischknecht and Braunschweig (2000) & & \\
\hline & Garnier-Laplace et al. (2009) & & \\
\hline & $\begin{array}{l}\text { USEtox (Rosenbaum et al. 2008) } \\
\text { (including indoor air extension of } \\
\text { Hellweg et al. 2009) }\end{array}$ & & \\
\hline & Meijer et al. (2005) & & $\begin{array}{r}\text { (Same as Frischknecht } \\
\text { and Braunschweig) }\end{array}$ \\
\hline \multirow[t]{4}{*}{ Additional models } & UNSCEAR (2000) & & \\
\hline & ERICA (Brown et al. 2008) & & \\
\hline & AMBER (Quintessa Ltd. 2014) & & \\
\hline & $\begin{array}{l}\text { Room models (reviewed in Risica } \\
\text { et al. 2001), Markkanen (1995) }\end{array}$ & & \\
\hline
\end{tabular}

incorporation of new nuclides practically impossible. In addition, the specificity of the model to the nuclear fuel cycle means that the results may not be an accurate representation of the fate of NORM releases to the environment. The F \& B fate model is not recommended for use in the incorporation of NORM into LCA, but may provide a useful comparative value (for ${ }^{238} \mathrm{U}$ ) for the model that is used/developed.

\subsubsection{Garnier-Laplace et al. (2009)}

The Garnier-Laplace model was developed as a screening approach to assess the potential impact of routine liquid releases from nuclear facilities to freshwaters. It considers the fate of nuclides into two compartments, the water itself and the sediment. It achieves this using a simple box dilution model, in which the concentration of a substance in a homogeneous section of the waterbody over a given fixed time period is equal to the rate of emission divided by the rate of dilution (in terms of water throughflow). The distribution coefficient $\left(K_{\mathrm{d}}\right)$ concept was applied to describe sorption of radionuclides in the water column to sediment. ${ }^{3}$ Uptake of the radionuclides into organisms is calculated by the concentration ratio $(\mathrm{CR})$. $K_{\mathrm{d}}$ and CR values are calculated using the ERICA model, discussed below.

Both radiological and toxic aspects of emitted isotopes are considered, covering only man-made isotopes. The method is based on the FASSET project characterisation factor database (which was later incorporated into a newer FREDERICA database (Frederica 2007)), and does not cover NORMs. The FASSET database is not published in the open literature.

The relation between the activity concentration and absorbed dose (exposure) is described by dose conversion coefficients (DCCs). The method is applied to the reference

\footnotetext{
3 The distribution coefficient is a ratio of the amount of the substance sorbed to the sediment (usually measured in $\mu \mathrm{g} / \mathrm{kg}$ ) to the amount of the substance in suspension in the water column (usually measured in $\mu \mathrm{g} / \mathrm{l}$ ) at equilibrium. The micrograms cancel out, leaving the $K_{\mathrm{d}}$ in units of litres per kilogram.
}

organisms in the freshwater environment, in order to determine the potentially affected fraction of living organisms per annum.

The Garnier-Laplace model does not include data for NORM nuclides; however, its overlap with ERICA, its potential compatibility with USEtox and its acceptance (at least as an interim choice at a midpoint level) by ILCD mean that it may have the potential to form a part of a NORM assessment.

\subsubsection{USEtox (Rosenbaum et al. 2008)}

The USEtox model was developed by the United Nations Environment Program (UNEP) and the Society for Environmental Toxicology and Chemistry (SETAC) in consultation with the developers of CalTOX, IMPACT 2002, USES-LCA, BETR, EDIP, WATSON and EcoSense, the leading toxicology models used in both environmental toxicology and LCA. It is a scientific consensus model, representing recommended practice within toxicological modelling in LCA. It is based on a matrix algebra framework, first proposed by Rosenbaum et al. (2007) and adopted in the OMNIITOX model. It assumes homogeneous and instantaneous mixing, calculating the increase in concentration of a chemical in all compartments as a result of its emission into one compartment. Transfer coefficients between compartments are calculated using the physical properties of the chemical in question (partition coefficients etc.). Chemical degradation within a compartment is included as a removal process. The further transportation and toxicity of degradation products are not accounted for by the model. This has implications for the assessment of radionuclides, since the release of ionising radiation by a radionuclide is commonly associated with its transmutation to another element. Following the USEtox approach sensu stricto, this would be considered degradation, and the subsequent decay chain would not be considered. Given the relative predictability of radioactive decay and the availability of dose conversion coefficients for 
Table 7 Summary of model review

\begin{tabular}{|c|c|c|c|c|c|}
\hline & $\begin{array}{l}\text { Frischknecht and } \\
\text { Braunschweig (2000) }\end{array}$ & $\begin{array}{l}\text { Garnier-Laplace } \\
\text { et al. (2009) }\end{array}$ & $\begin{array}{l}\text { USEtox (Rosenbaum } \\
\text { et al. 2008) }\end{array}$ & Hellweg et al. (2009) & Meijer et al. (2005a) \\
\hline $\begin{array}{l}\text { Completeness of } \\
\text { scope }\end{array}$ & $\begin{array}{l}\text { Emissions to air and water } \\
\text { included } \\
\text { Occupational exposure and } \\
\text { indoor } \\
\text { exposure are not included } \\
\text { Includes exposure and damage } \\
\text { factors for the release of } \\
{ }^{238} \mathrm{U}, \\
\text { not for }{ }^{232} \mathrm{Th} \text { or }{ }^{40} \mathrm{~K}\end{array}$ & $\begin{array}{l}\text { Only emissions to freshwater } \\
\text { included } \\
\text { Only applicable to midpoint } \\
\text { level } \\
\text { No NORM nuclides included }\end{array}$ & $\begin{array}{l}\text { Includes all relevant } \\
\text { environmental } \\
\text { compartments, including } \\
\text { subdivision at continental } \\
\text { and global scale for air, and } \\
\text { freshwater, ocean, natural } \\
\text { and agricultural soil, as } \\
\text { well } \\
\text { as urban air } \\
\text { Inorganic chemicals, including } \\
\text { metals included, but no } \\
\text { NORM } \\
\text { nuclides included }\end{array}$ & $\begin{array}{l}\text { Extension to the USEtox } \\
\text { model } \\
\text { Includes both occupational } \\
\text { and residential air, for a } \\
\text { European and US setting. } \\
\text { The model is linked to } \\
\text { USEtox } \\
\text { No specific chemical data is } \\
\text { included; however, the } \\
\text { equations are chemical } \\
\text { independent }\end{array}$ & $\begin{array}{l}\text { Model for indoor residential } \\
\text { air and exposure from } \\
\text { building materials }{ }^{232} \mathrm{Th} \\
\text { and }{ }^{40} \mathrm{~K} \text { are included as } \\
\text { gamma emitters. }{ }^{226} \mathrm{Ra} \\
\text { (a member of the }{ }^{238} \mathrm{U} \\
\text { decay chain) is included } \\
\text { as a gamma emitter } \\
{ }^{222} \mathrm{Ra} \text { as an emission to } \\
\text { indoor } \\
\text { air is included separately. } \\
\text { Includes damage assessment } \\
\text { (of Frischknecht and } \\
\text { Braunschweig) }\end{array}$ \\
\hline Model relevance & $\begin{array}{l}\text { Modelling is only specific to } \\
\text { elements of the nuclear fuel } \\
\text { cycle } \\
\text { Considered (by ILCD) } \\
\text { applicable } \\
\text { at a global scale }\end{array}$ & $\begin{array}{l}\text { Specific to freshwater releases, } \\
\text { although model is general } \\
\text { Limited to artificial } \\
\text { radionuclides } \\
\text { from nuclear fuel cycle }\end{array}$ & $\begin{array}{l}\text { Highly relevant to } \\
\text { environmental releases of } \\
\text { toxic substances at a local, } \\
\text { continental and global scale }\end{array}$ & $\begin{array}{l}\text { Highly relevant to indoor } \\
\text { releases of toxic substances }\end{array}$ & $\begin{array}{l}\text { Highly relevant to TENORM } \\
\text { exposure in use phase }\end{array}$ \\
\hline $\begin{array}{l}\text { Robustness and } \\
\text { certainty }\end{array}$ & $\begin{array}{l}\text { Model is scientifically robust, } \\
\text { peer reviewed and well } \\
\text { documented } \\
\text { Uncertainty is reported }\end{array}$ & $\begin{array}{l}\text { Model is robust and peer } \\
\text { reviewed } \\
\text { Many factors have been } \\
\text { superseded by ERICA }\end{array}$ & $\begin{array}{l}\text { Model is scientifically robust } \\
\text { and represents best practice } \\
\text { for environmental } \\
\text { toxicological modelling }\end{array}$ & $\begin{array}{l}\text { The model is robust from a } \\
\text { scientific perspective } \\
\text { A great deal of variation in the } \\
\text { size, ventilation and use of } \\
\text { indoor areas exists } \\
\text { (particular } \\
\text { in occupational settings); } \\
\text { therefore, there is some } \\
\text { uncertainty around the } \\
\text { results. }\end{array}$ & $\begin{array}{l}\text { The model is robust from a } \\
\text { scientific perspective } \\
\text { Uncertainty related to } \\
\text { variation } \\
\text { in room dimensions is } \\
\text { assessed } \\
\text { and considered low for } \\
\text { residential applications }\end{array}$ \\
\hline Applicability & $\begin{array}{l}\text { Has been incorporated into } \\
\text { LCA NORM processing } \\
\text { not analogous to nuclear } \\
\text { fuel cycle } \\
\text { Modelling dependent on } \\
\text { similar population density/ } \\
\text { meteorology }\end{array}$ & $\begin{array}{l}\text { Has been incorporated into LCA } \\
\text { Model is general and adaptable } \\
\text { Principles of the model are } \\
\text { transparent and compatible } \\
\text { with the USEtox framework }\end{array}$ & $\begin{array}{l}\text { Developed specifically for } \\
\text { use in LCA } \\
\text { Specifically developed for } \\
\text { long-erm continuous } \\
\text { emissions }\end{array}$ & $\begin{array}{l}\text { Developed specifically for use } \\
\text { in LCA } \\
\text { Only applicable to indoor } \\
\text { emissions, } \\
\text { but linked to the rest of } \\
\text { USEtox }\end{array}$ & $\begin{array}{l}\text { The method was developed } \\
\text { specifically for LCA } \\
\text { Standard room used is } \\
\text { considered valid in the } \\
\text { Dutch setting, and is } \\
\text { likely } \\
\text { to be applicable in a pan- } \\
\text { European setting. }\end{array}$ \\
\hline $\begin{array}{l}\text { Transparency and } \\
\text { reproducibility }\end{array}$ & $\begin{array}{l}\text { Documentation is } \\
\text { comprehensive; } \\
\text { however, translation from } \\
\text { data } \\
\text { sources to figures given is } \\
\text { opaque }\end{array}$ & $\begin{array}{l}\text { Model and equations are } \\
\text { transparently presented }\end{array}$ & $\begin{array}{l}\text { Documentation is } \\
\text { comprehensive } \\
\text { and the model itself is } \\
\text { freely available }\end{array}$ & $\begin{array}{l}\text { The model is transparent and } \\
\text { well } \\
\text { documented, but not yet } \\
\text { released }\end{array}$ & $\begin{array}{l}\text { The model is transparent } \\
\text { and equations are well } \\
\text { documented }\end{array}$ \\
\hline $\begin{array}{l}\text { Stakeholders' } \\
\text { acceptance }\end{array}$ & $\begin{array}{l}\text { Recommended by ILCD at } \\
\text { midpoint level } \\
\text { Included in LCA software } \\
\text { Peer reviewed paper has } 29 \\
\text { citations }\end{array}$ & $\begin{array}{l}\text { Recommended, as an interim } \\
\text { method, by ILCD at } \\
\text { midpoint level } \\
\text { Included in LCA software } \\
\text { Peer reviewed paper has } 7 \\
\text { citations }\end{array}$ & $\begin{array}{l}\text { Considered de facto standard } \\
\text { for fate and toxicity } \\
\text { modelling in } \\
\text { LCA by the ILCD, and the } \\
\text { wider LCA community } \\
\text { Included in LCA software } \\
\text { Peer-reviewed paper has over } \\
430 \text { citations }\end{array}$ & $\begin{array}{l}\text { The USEtox model on which } \\
\text { this } \\
\text { approach is based is highly } \\
\text { regarded } \\
\text { Peer-reviewed paper has } 8 \\
\text { citations }\end{array}$ & $\begin{array}{l}\text { Published in peer-reviewed } \\
\text { journal } \\
\text { Paper has } 25 \text { citations; } \\
\text { however, } \\
\text { the majority are related to } \\
\text { organic chemical aspects } \\
\text { No explicit case studies in } \\
\text { relation to radiological } \\
\text { impact }\end{array}$ \\
\hline
\end{tabular}

\begin{tabular}{|c|c|c|c|c|}
\hline & UNSCEAR (2000) & ERICA (Brown et al. 2008) & $\begin{array}{l}\text { AMBER (Quintessa Ltd. } \\
\text { 2014) }\end{array}$ & Markkanen (1995) \\
\hline $\begin{array}{l}\text { Completeness of } \\
\text { scope }\end{array}$ & $\begin{array}{l}\text { Covers both gamma exposure } \\
\left({ }^{238} \mathrm{U},{ }^{232} \mathrm{Th},{ }^{40} \mathrm{~K} \text { series }\right) \text { and } \\
\text { radon inhalation/ingestion by } \\
\text { humans for indoor environment } \\
\text { and provides coefficients for } \\
\text { outdoor exposure based on the } \\
\text { isotope concentration in soil }\end{array}$ & $\begin{array}{l}\text { Fate assessment is available for small } \\
\text { and large lakes, rivers, estuaries and } \\
\text { air } \\
\text { Only exposure of biota is considered, } \\
\text { using ICRP reference organisms } \\
{ }^{40} \mathrm{~K} \text { is not included, but }{ }^{238} \mathrm{U} \text { and }{ }^{232} \mathrm{Th} \\
\text { are included } \\
\text { Damage assessment included but } \\
\text { limited }\end{array}$ & $\begin{array}{l}\text { The tool provides a framework } \\
\text { for isotope transfer in the } \\
\text { environment } \\
\text { Includes isotope transfer in water, } \\
\text { air, ground and food chains } \\
\text { External and internal exposure } \\
\text { modelling is available } \\
\text { The user can model specific } \\
\text { geographical location } \\
\text { Users must manually input } \\
\text { the isotopes, their } \\
\text { characterisation coefficients } \\
\text { and considered pathways, }\end{array}$ & $\begin{array}{l}\text { Covers in detail indoor exposure from } \\
\text { gamma emitters }\left({ }^{238} \mathrm{U},{ }^{232} \mathrm{Th} \text { series }\right. \\
\left.\text { and }{ }^{40} \mathrm{~K}\right) \\
\text { Covers gamma ray exposure from } \\
\text { stockpiles and/or landfills, } \\
\text { including inhalation exposure } \\
\text { from dust }\end{array}$ \\
\hline
\end{tabular}


Table 7 (continued)

\begin{tabular}{|c|c|c|c|c|}
\hline & UNSCEAR (2000) & ERICA (Brown et al. 2008) & $\begin{array}{l}\text { AMBER (Quintessa Ltd. } \\
\text { 2014) }\end{array}$ & Markkanen (1995) \\
\hline & & & $\begin{array}{l}\text { requiring significant manual } \\
\text { effort }\end{array}$ & \\
\hline Model relevance & $\begin{array}{l}\text { Highly relevant to NORM } \\
\text { in building materials }\end{array}$ & $\begin{array}{l}\text { Highly relevant up to midpoint } \\
\text { level for biota }\end{array}$ & $\begin{array}{l}\text { Relevance depends on ability of } \\
\text { user to provide sufficient } \\
\text { input data }\end{array}$ & $\begin{array}{l}\text { Relevant to occupation exposure from } \\
\text { storage, NORM in building } \\
\text { materials } \\
\text { and landfilled wastes }\end{array}$ \\
\hline \multirow[t]{2}{*}{$\begin{array}{l}\text { Robustness and } \\
\text { certainty }\end{array}$} & \multirow[t]{2}{*}{$\begin{array}{l}\text { Model and equations are } \\
\text { scientifically robust }\end{array}$} & $\begin{array}{l}\text { Methodology incorporates state of } \\
\text { the art of knowledge }\end{array}$ & $\begin{array}{l}\text { The model lacks discussions in } \\
\text { journal articles }\end{array}$ & \multirow[t]{2}{*}{$\begin{array}{l}\text { Model and equations are scientifically } \\
\text { robust }\end{array}$} \\
\hline & & $\begin{array}{l}\text { Dispersion models and exposure } \\
\text { coefficients applied are those } \\
\text { recommended by IAEA and ICRP } \\
\text { Uncertainties are provided separately } \\
\text { for every dispersion model }\end{array}$ & $\begin{array}{l}\text { It has been tested by IAEA in the } \\
\text { EMRAS report (IAEA 2007), } \\
\text { which noted its potential and } \\
\text { flexibility but also its complexity }\end{array}$ & \\
\hline Applicability & Can be applied directly to LCA & $\begin{array}{l}\text { Can be applied in LCA with } \\
\text { revisions/additions }\end{array}$ & $\begin{array}{l}\text { Commercial nature of tool } \\
\text { restricts applicability } \\
\text { Individual sites must be } \\
\text { modelled separately }\end{array}$ & $\begin{array}{l}\text { Can be applied directly in LCA with } \\
\text { assumptions regarding stockpile/ } \\
\text { landfill geometry and additional } \\
\text { data required for room } \\
\text { characteristics }\end{array}$ \\
\hline $\begin{array}{l}\text { Transparency and } \\
\text { reproducibility }\end{array}$ & $\begin{array}{l}\text { Model description and equations } \\
\text { are published and well described }\end{array}$ & $\begin{array}{l}\text { All coefficients, models and } \\
\text { equations used have been } \\
\text { documented and presented } \\
\text { in the literature } \\
\text { The model documentation is } \\
\text { published and accessible }\end{array}$ & $\begin{array}{l}\text { The principles of the model are } \\
\text { vague and unclear } \\
\text { The tool is commercial and has } \\
\text { paid licence }\end{array}$ & $\begin{array}{l}\text { Model description and equations } \\
\text { are published and well described }\end{array}$ \\
\hline $\begin{array}{l}\text { Stakeholders' } \\
\text { acceptance }\end{array}$ & $\begin{array}{l}\text { The methodology has been } \\
\text { presented } \\
\text { on behalf of a UN Scientific } \\
\text { Committee }\end{array}$ & $\begin{array}{l}\text { Developed by more than } 60 \\
\text { scientists around the world, } \\
\text { including regulators and policy } \\
\text { makers } \\
\text { Characterisation factors for reference } \\
\text { organisms are based on the } \\
\text { recommendations of ICRP (2008). } \\
\text { Dispersion models are recommended } \\
\text { by IAEA ( } 2001)\end{array}$ & $\begin{array}{l}\text { The model has been used by } \\
\text { the IAEA but not explicitly } \\
\text { endorsed }\end{array}$ & $\begin{array}{l}\text { The model proposed by Markkanen } \\
\text { has been developed for Finnish } \\
\text { Centre for Radiation and Nuclear } \\
\text { Safety and published in a report, } \\
\text { not in a journal. However, this work } \\
\text { is well recognised in the field and } \\
\text { referenced in a number of sources } \\
\text { including EU and IAEA reports }\end{array}$ \\
\hline
\end{tabular}

complete decay chains, it would be desirable to include full decay chain effects for NORM radionuclides.

In addition to freshwater, ocean, natural and agricultural soil (each subdivided at a continental and global scale), the USEtox model includes compartments for global, continental and urban air, and, in the latest release version (USEtox 2.01), indoor air, after Hellweg et al. (2009).

No data for radionuclides is included in USEtox currently; however, sourcing suitable data is anticipated to be relatively straightforward. Given the comprehensive nature of the fate modelling and its broad acceptance as best practice, USEtox has great potential for use in NORM fate modelling.

\subsubsection{Meijer et al. $(2005 a, b)$}

The Meijer model explicitly aims to integrate indoor air exposure of humans to organic compounds, radon and gamma radiation into LCA. It treats radon in terms of its exhalation potential from the building materials and gamma radiation as a direct emission to the air, with the resulting fate factors in units of sieverts per becquerel. ${ }^{222} \mathrm{Rn}$ (from the ${ }^{238} \mathrm{U}$ decay chain) is the main form of radon considered to be a health risk. It is the daughter isotope of radium- $226\left({ }^{226} \mathrm{Ra}\right)$. The exposure factors used for ${ }^{226} \mathrm{Ra}$ are recorded as ${ }^{238} \mathrm{U}$ in the original reference quoted by Meijer et al. (Koblinger 1984). This equivalence holds while the two isotopes are in secular equilibrium, a state at which the rate of decay for a daughter radionuclide is limited by and therefore identical to that of its parent radionuclide. Secular equilibrium can have the appearance of a stable state where the half-life of the parent isotope is very long, as is the case with ${ }^{238} \mathrm{U}\left(t_{1 / 2}=4.5\right.$ billion years), provided that the parent and daughter isotopes remain co-located following the establishment of equilibrium. For natural building materials, like stone, this is likely to be the case. For processed materials, such as bauxite residue, the more water-soluble ${ }^{226}$ Ra may not remain co-located with its parents as it may have been partially washed away by process water. Once the equilibrium state has been disturbed in this way, it can take thousands of years to re-establish; therefore, to apply the method of Meijer et al., ${ }^{238} \mathrm{U}$ and ${ }^{226} \mathrm{Ra}$ activity may need to be recorded separately in LCI and the exposure factors may need to be revised for processed materials.

For the gamma emitters, exposure modelling is carried out for two compartments, a first floor room and a second floor room, based on the proportion of time spent in each compartment by the occupants of the house (50 and 30\%, respectively, with the remainder of time not spent in the house). The room models are based on a standard room of $4 \times 5 \times 2.8 \mathrm{~m}$, with a 
wall thickness of $20 \mathrm{~cm}$. It assumes a uniform and homogeneous radiation field within the compartments and that the effect only takes place within the compartment itself. It also assumes a linear relationship between the intensity of the radiation field and both wall thickness (up to $30 \mathrm{~cm}$ ) and building material density.

The standard room used is considered valid in the Dutch setting and is likely to be applicable in a pan-European setting; however, it may not be more broadly applicable worldwide.

The Meijer et al. model is explicitly designed for use in LCA, and although it has yet to be cited in the scientific literature as the basis for case studies in radiological impact, it is nevertheless considered a robust method for accounting for radiological impact of building materials, provided that the ${ }^{226} \mathrm{Ra} /{ }^{238} \mathrm{U}$ equilibrium issue is investigated and resolved.

\subsubsection{ERICA}

The ERICA tool is a software package designed to assess sitelevel environmental impact due to radionuclide releases (Brown et al. 2008). The model allows for fate and exposure assessment. The environmental transfer of isotopes and exposure of the biota is assessed, and the model includes major NORMs. There are different options for radionuclide fate assessment: (i) one of several predefined transport models can be used, or (ii) a dispersion model can be implemented by the user. The predefined models within ERICA are referred to as SRS-19 models, recommended in the report by the International Atomic Energy Agency (IAEA 2001). The models estimate radionuclide concentrations in the air/water from a single ejection source assuming secular equilibrium between release and the environmental medium. The models do not correspond to any specific country or region and represent the ecosystem in a general way. The drawback of the predefined models is that they focus on isotope transfer only within a single compartment (i.e. a river).

The ERICA tool incorporates state-of-the-art knowledge regarding biota exposure to ionising radiation. Exposure is calculated by summing up internal and external absorbed dose rates applying predefined conversion coefficients and weighing factors. Reference organisms recommended by ICRP (2008) are considered for terrestrial, marine and freshwater environments. Ionising radiation exposure conversion coefficients and weighing factors are applied for characteristic living organisms in each of these ecosystems. The tool includes not only artificial radionuclides but also major NORMs.

The FREDERICA (Copplestone et al. 2008) database is used for damage characterisation in the ERICA tool. Based on the exposure dose, the radiation effects on reference groups of living organisms are provided. On the one hand, both deterministic and stochastic effects are considered; on the other hand, the database has significant gaps, especially at low dose rates. It cannot be recommended at this point for the endpoint level of impact assessment.

The ERICA methodology presents a limited capacity for fate and damage analysis in the context of LCA; however, the exposure assessment is of sufficient quality to be applicable to the LCA NORM assessment. The database is not complete, however, and for some isotopes, concentration ratios for some of the reference organisms are not defined. The fate modelling coefficients for NORM isotopes contained within the model may be utilised in other models.

\subsubsection{AMBER}

AMBER is a compartmental analysis software tool (Quintessa Ltd. 2014) that allows users to build dynamic models in order to represent the migration and fate of radionuclide isotopes in the environmental system. The tool can be applied for a detailed assessment level within terrestrial, aquatic and atmospheric dispersion. The code includes NORM contamination and food-chain models, as well as leaching of radionuclides which allows for explicit fate assessment and provides a wide range of modelling capacities.

The main drawbacks of the AMBER tool are the need for manual input of the radionuclide characterisation coefficients and considered pathways, as well as the need to set up the environmental models manually. The code has been stated by the IAEA to be complex and time consuming for a new user (IAEA 2007). In addition, it is a proprietary tool, and as such the modelling and documentation are not transparent. The complexity and specificity of the tool are such that it cannot be recommended for the purposes of LCA.

\subsubsection{UNSCEAR}

The UNSCEAR report (UNSCEAR 2000) provides guidelines for a thorough assessment of the impact of ionising radiation on humans in the indoor and outdoor environments. The report provides a list of recommended equations and exposure coefficients (as well as occupancy factor and absorbed to effective dose conversion coefficient). The model is based on systematic measurements and analysis that cover around $45 \%$ of the world human population. Based on the data, a set of coefficients and characterisation factors is provided to assess the annual effective dose (in man.Sv). The model includes coefficients for NORM materials. The report provides a clear overview of the methodology that can be used for model implementation and further development. The methodology is generic and can be easily applied in the LCA for effective dose assessment, based on the known exposure dose for external exposure (in Gy) and based on isotope intake for internal exposure (in $\mathrm{Bq}$ ). The model provides coefficients for a reference person (man or woman with defined anatomy), babies and infants. 
For the outdoor environment, the model concerns the concentration of NORM elements in the ground and provides exposure coefficients for ${ }^{232} \mathrm{Th},{ }^{238} \mathrm{U}$ groups and ${ }^{40} \mathrm{~K}$ for effective dose estimation due to the NORMs presented in soil. The coefficients are presented for gamma exposure from the whole decay chain and not separated for individual nuclides (as the secular equilibrium of the decay chains is assumed). The methodology for outdoor impact assessment is considered to be inadequate for LCA.

For the indoor environment, the dose is split into external gamma dose and internal due to isotope inhalation/digestion. External gamma dose coefficients are provided for ${ }^{232} \mathrm{Th}$, ${ }^{238} \mathrm{U}$ groups and ${ }^{40} \mathrm{~K}$ for effective dose estimation due to the NORMs presented in soil. The model provides coefficients for these isotopes in the ground, without treating building materials in a separate manner. Internal dose coefficients (for ${ }^{232} \mathrm{Th}$ and ${ }^{238} \mathrm{U}$ decay series radionuclides not ${ }^{40} \mathrm{~K}$ ) as well as reference annual food, water and air consumptions rates are published. Radon is treated in a separate, more detailed manner. Based on the radon flux inside building material, the rate of isotope release to the building and the concentration can be determined. Separate equations for exposure are provided for radon inhalation and ingestion (considering decay products of radon).

The UNSCEAR model allows us to implement a generalised approach for exposure estimation. The damage is covered to a certain extent - tables are provided with summarised observed and experimental data for cancer and mortality rates based on the absorbed effective dose. The model allows us to determine the fate of radon inside building materials and exposure of the population based on the wall flux of radon. For the external gamma dose, the model covers whole-body exposure due to the presence of NORM within soil, considering exposure from the whole decay chain. Overall, the methodology is transparent and well documented, making it a good choice for implementing within LCA, with some minor modifications (i.e. a separate external gamma-exposure model has to be applied). It is important to mention that a set of up-todate coefficients is presented within the ICRP report (ICRP 2012), where separate exposures are distinguished between workers and the public for ingestion and inhalation of the isotopes.

\subsubsection{Room models for indoor exposure estimation (Markkanen 1995; Risica et al. 2001)}

A review of several room models is provided by Risica et al. (2001). All of the models are used to estimate indoor gamma exposure due to NORMs incorporated in construction materials. All of the models require some or all of the following parameters: specific room dimensions, material density and wall thickness, locations for windows and doors. Secular equilibrium of ${ }^{238} \mathrm{U}$ and ${ }^{232} \mathrm{Th}$ is assumed, despite the fact that $\mathrm{Rn}$ is known to escape from the building materials. Such an approach is more detailed than the UNSCEAR model, discussed above (which provides coefficients for external exposure from the whole ${ }^{238} \mathrm{U}$ and ${ }^{232} \mathrm{Th}$ decay chains due to their presence in the ground) and might be used as a complimentary tool for predicting the absorbed dose based on the radionuclide concentration within building materials, which will then be converted to the effective dose with the help of the UNSCEAR model.

The most recent among the models reviewed by Risica is that of Markkanen (1995). This model allows us to assess gamma rate exposure due to ${ }^{238} \mathrm{U},{ }^{232} \mathrm{Th}$ decay chains and ${ }^{40} \mathrm{~K}$. However, instead of ${ }^{238} \mathrm{U}$, which is an alpha emitter and cannot be easily measured, the concentration of ${ }^{226} \mathrm{Ra}$, widely used as a reference for ${ }^{238} \mathrm{U}$, is used in the model to assess the gamma exposure from the whole chain (decay steps from ${ }^{238} \mathrm{U}$ to ${ }^{226} \mathrm{Ra}$ result in emitted gamma photons with low energies that have minor exposure, compared to the decay of ${ }^{226} \mathrm{Ra}$ and its progenies).

The model allows connecting annual exposure with the concentration of the isotopes inside of the building material and therefore is a potential candidate as an alternative for absorbed dose assessment. The same coefficients are used by the UNSCEAR and Markkanen to convert the absorbed dose to the annual effective dose. The Meijer model is considered a better option for LCA, however, as it performs the same function, but is designed for use in LCA.

\subsubsection{Industrial storage, landfill and handling}

Occupational exposure to radiation is yet to be explicitly considered in LCA; indeed, Frischknecht and Braunschweig (2000) explicitly exclude occupational exposure from the current ionising radiation categorisation method, on the grounds of consistency, using the example that pneumoconiosis in coal miners is not included in the eco-indicator method (Goedkoop et al. 1998). Methods to include occupational risks to human health have been proposed, including risk-based approaches related to legislative exposure limits (Wenzel et al. 2000); 'bottom-up' approaches, considering direct inhalation of chemical releases (Hellweg et al. 2005; Hellweg et al. 2009); and 'top-down' approaches using input-output modelling in conjunction with industrial accident and illness statistics (Hofstetter and Norris 2003). None of these methods are widely used at present, and none explicitly include radiation exposure.

Gamma-emitting radionuclides within material stored at industrial and landfill sites have the potential to have a radiological impact on humans managing these storage areas. The shielding effect of outer layers of the material stockpile on the inner layers means that the exposure of the receptor to the gamma source will be limited to the upper stockpile layers and the dust that contains volatile radionuclides. Based on 
the geometry of the stockpile or landfill site, the external dose rate by gamma radiation can be assessed using the model proposed in Markkanen (1995). The gamma exposure caused by a pile of material is assessed based on the distance of the worker and the amount of the material. In case landfilled or stockpiled material is raising dust, Markkanen provides an equation to assess the internal dose based on the dust concentration and activity.

The direct gamma radiation impact on workers from handling NORM materials during processing (that is once they have been removed from storage and are being prepared for reuse) is likely to be negligible in a life cycle context. In the case of BR valorisation, it is estimated that handling times during processing are likely to be measured in hours, rather than days (ETN-MSCA REDMUD project members, pers. comm.). Given that TENORM residues may spend 70 years or more in building materials, or a number of years in stockpiles/landfills, the potential for exposure during material handling is considered to be low in comparison. No current model exists to account for this type of exposure, and given its lack of significance, it is not recommended that such a model be developed.

\subsection{Framework development}

Figure 3 sets out our proposed framework for the inventory and classification of NORM, based on our results in Sections 3.2-3.3. The grey boxes represent the familiar elements of an LCA, namely the life cycle inventory (LCI), the midpoint indicator and the endpoint indicator. The remaining boxes and arrows represent the intermediate calculation stages required to calculate the necessary characterisation factors.
The sources of radiation considered in the framework are nuclide emissions to air, nuclide emissions to water, nuclides in industrial storage (e.g. ore stockpiles, residual material landfills) and nuclides in building materials. All of these inventory items are relevant to human receptors, while only releases to air and water are relevant to ecosystems.

Within the LCA domain, the first step is to define clear elementary flows, which can be scaled to a functional unit and which allows the aggregation of LCI results. For NORM, the elementary flow to consider is the amount of each radioisotope, measured in terms of activity, rather than mass, in the unit of becquerel $(\mathrm{Bq})$.

Separate modelling approaches are required to establish the fate of each of these elementary flows. Once the fate of the nuclides has been established for each cause-effect chain, the exposure of the receptor to the nuclide must then be established, in order to calculate the dose of radiation received by the relevant receptors. This dose measurement is suggested to constitute the midpoint indicator, represented in units of effective dose per becquerel inventoried $\left(\mathrm{Sv} \mathrm{Bq}^{-1}\right)$. The exposure model for NORM in building materials will represent the additional dose received by human receptors from the built environment as a result of increased activity in the materials used.

From the calculated midpoint indicators for human and ecosystem exposure, it may be possible to model the potential damage caused as a result of the dose received, in order to calculate an endpoint indicator. Only two of the models reviewed contain a damage assessment (note the damage assessment used in Meijer et al. is that from Frischknecht and Braunschweig), one for humans and one for ecosystems. The human damage assessment of Frischknecht and Braunschweig is relatively robust, and their endpoint value is recommended at an interim level by the ILCD a) Human Health

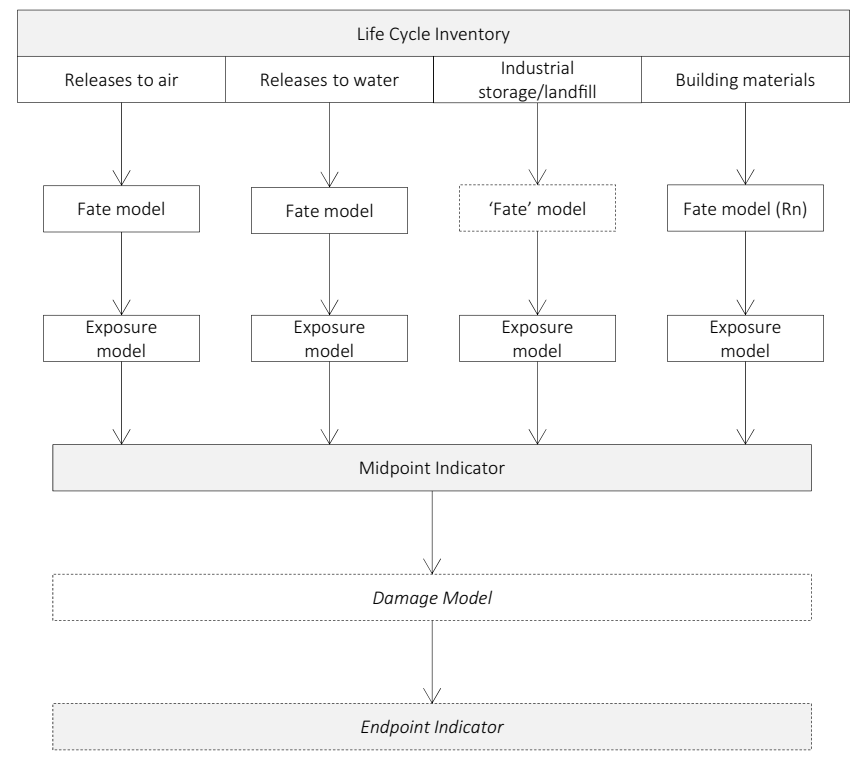

b) Ecosystems

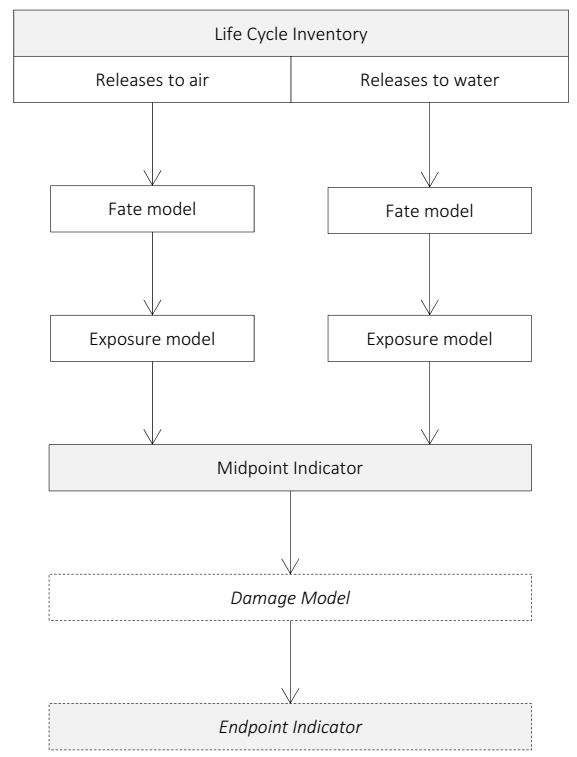

Fig. 3 Proposed framework for NORM assessment in LCA 
(Hauschild et al. 2013). The damage assessment for ecosystems outlined in the Garnier-Laplace model is less robust and is not recommended for use by the ILCD.

The most applicable models reviewed in Section 3.3 for each stage in the above framework are shown in Table 8, along with an indication of the amount of revision required for their successful incorporation.

At the inventory analysis stage, for environmental releases, direct measurement is unlikely to be possible; therefore, a mass balance approach, based on the activity of the incoming materials and the eventual product, may be required to estimate radionuclide releases. For industrial storage and final products, the activity concentration of the materials should be estimated from available literature or established through direct measurement.

At the fate analysis stage, the USEtox model is recommended for environmental releases. It is a mature methodology implemented and widely used within LCA for environmental hazardous material fate assessment. However, the USEtox model does not consider decay products and different environmental behaviour of daughter nuclides. It is recommended that the effects of the full decay chains are taken into account, since they arise from elements with different physical and chemical properties.

For the indoor NORM fate assessment, it is assumed that all of the isotopes (except radon) are bound within construction material throughout the lifetime of the material. This is a reasonable assumption, since all the radioisotopes other than radon make a minor contribution to internal exposure (UNSCEAR 2000). It is proposed that the fate of radon in the indoor environment is calculated separately using the UNSCEAR models, which allows the prediction of indoor concentration and exposure from radon based on the concentration of the isotope in the specific construction material and its properties.

For the exposure assessment in terms of humans, UNSCEAR provides robust models for both indoor and outdoor analyses. The exposure assessment from the Meijer model can be used to assess the external dose received from gamma emitters in building materials, based on average room dimensions and occupancy. The ERICA tool is considered to be the best option for biota exposure analysis, as it utilises the most recent database of exposure characterisation factors for the reference organisms, and includes major NORM elements.

There is no suitable methodology available to properly describe damage caused by ionising radiation on biota; however, the method of Garnier-Laplace is a good starting point. To assess damage on humans, the disability adjusted life years (DALY) approach used by Frischknecht and Braunschweig (2000) is the best available approach. In both cases, it may transpire in implementation that the uncertainty associated with the damage assessment will lead to the recommendation that the impact is only characterised to a midpoint (dose) level.

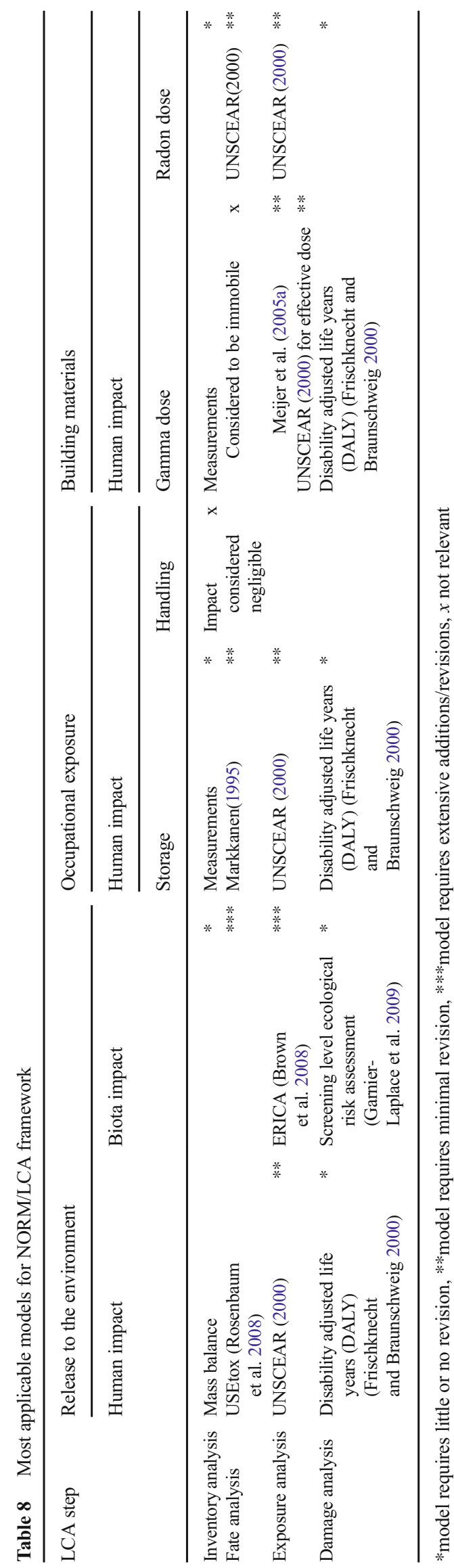




\section{Discussion}

Our research indicates that the inclusion of ionising radiation resulting from enhanced NORM exposure within the LCA framework is indeed desirable. We would suggest that it be incorporated alongside the existing ionising radiation models recommended by ILCD (European Commission 2011) for the nuclear fuel cycle, as a subcategory of the ionising radiation category, in a situation similar to 'cancer' and 'non-cancer' effects within human toxicity (Fig. 4). This requires the development of impact assessment models for each of the exposure routes outlined above. It is not recommended that the existing ionising radiation impact assessment models of Frischknecht and Braunschweig (2000) and Garnier-Laplace et al. (2009) be subsumed within the newly proposed framework. These more specific models relate directly to environmental releases occurring as a result of the nuclear fuel cycle, and as a result, the more specific fate and exposure modelling related to nuclides only produced in this industry are preferable to the more generalised approach outlined here. Environmental releases of NORM nuclides on the other hand are an issue for a far broader and more diverse set of industries, and therefore, a more generally applicable modelling approach is warranted.

The most significant potential exposure route to humans is anticipated to be through the presence of NORM in building materials, leading to exposure during the use phase; however, a holistic approach which also incorporates environmental and occupational exposures would be required in order to prevent burden shifting within the life cycle.

Existing models from the field of radiological protection as well as those developed specifically for LCA can provide the building blocks for the development of this characterisation method. The framework we outline here identifies the most suitable pieces and provides the 'blueprint' for putting these pieces together.

The use of industrial wastes and residues in useful products, particularly in construction products, is often stated as being 'eco-friendly'. This assertion is frequently based on the assumption that waste can cause environmental damage, so reducing it is a good thing (Chen et al. 2011), or that a reduced energy requirement, either in the extraction or processing of materials, is good for the environment (Ahmari and Zhang 2012). In many cases, these are reasonable assumptions, and the latter even hints at life cycle thinking, even if not validated by life cycle assessment. The development of novel materials based on such premises does, however, raise the spectre of burden shifting, either within the life cycle (from waste treatment to processing/use) or between impact categories.

For TENORM materials, the lack of a suitable impact category means that the radiological impact associated with their processing and use currently goes unassessed. As a result, seemingly 'eco-friendly' materials, even those validated by LCA, may in fact result in unnoticed but unacceptable increases in radiological impact. Indeed, Hellweg et al. (2005) point out that the lack of adequate LCA methods to assess workplace exposure to chemicals has the potential to lead to well-reasoned process optimisations which in actual fact cause a severe detriment to worker's health. NORM exposure currently represents a similar 'blind-spot' for LCA, which the framework set out here has the potential to address.

While this research indicates that the development of a NORM exposure impact category is possible, a number of
Fig. 4 Proposed placement of NORM exposure in the LCA framework. Diagram adapted from European Commission (2010), using classifications from European Commission (2011). New ionising radiation models are shown in bold. Solid black lines indicate those methods recommended by ILCD, dashed lines those recommended at interim level and grey lines not recommended

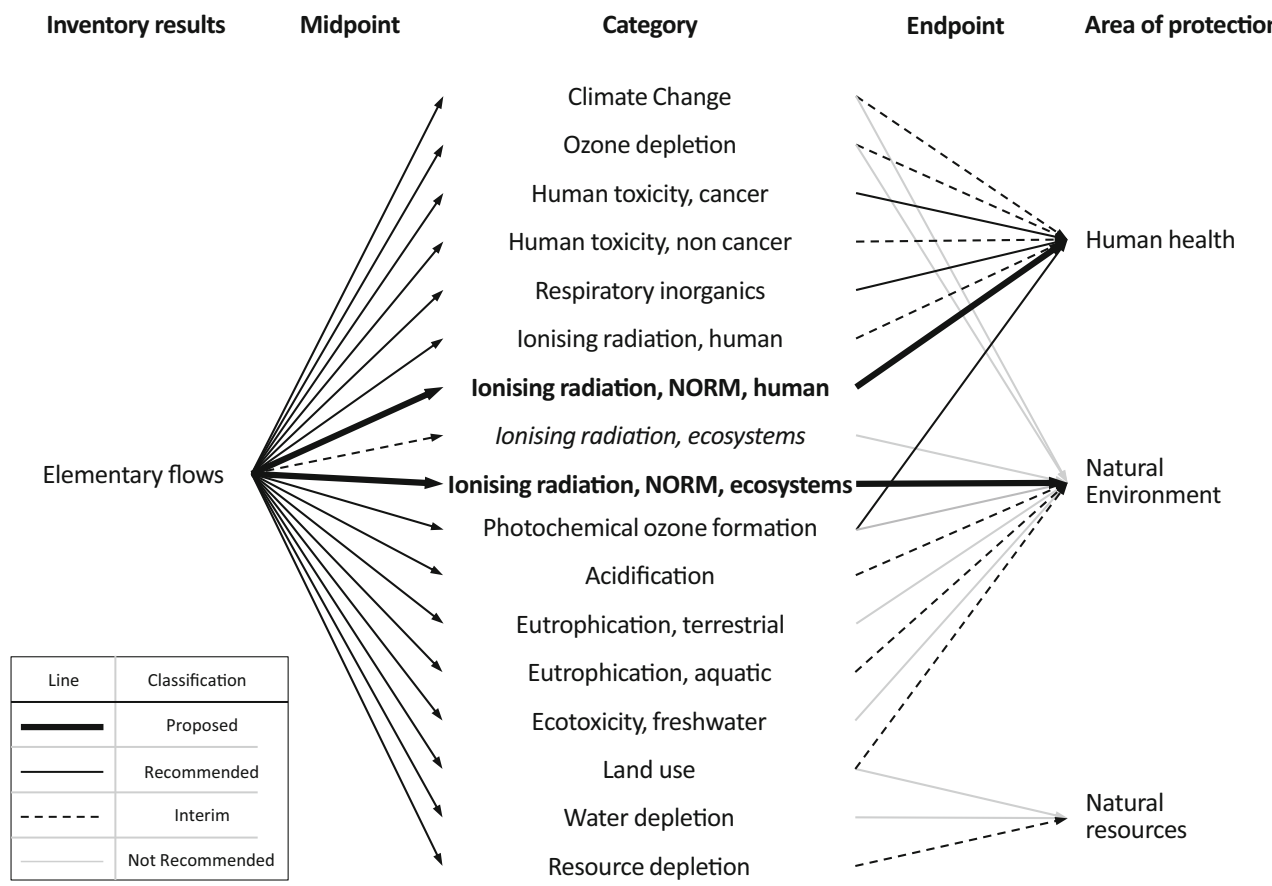


hurdles remain to be overcome. A multidisciplinary approach, incorporating aspects radiological modelling and radioprotection alongside LCA, is vital for this task. Firstly, a number of the models require NORM-specific parameters to be sourced, verified and then incorporated. The most significant of these is the USEtox model for environmental fate modelling, for which transfer coefficients and/or a range of physico-chemical properties must be included. Gaps are also present in the ERICA exposure model, regarding data for ${ }^{40} \mathrm{~K}$.

Secondly, the fate of radium within processed building materials derived from TENORMs needs to be established to verify the implicit assumption in the Meijer model that ${ }^{238} \mathrm{U}$ remains in secular equilibrium with ${ }^{226} \mathrm{Ra}$. This will need to be achieved through empirical testing (e.g. gamma spectroscopy) of representative TENORM materials, such as those generated by the ETNMSCA REDMUD project.

Lastly, the models in the framework should be consolidated into a single model (or 'meta'-model), such that all of the parameters for all of the models can be entered in one place, and the combined set of models run to generate the characterisation factors. This means that should better data become available in future, or more specific data be available for a particular case study, the characterisation factors can be updated quickly and simply.

\section{Conclusions}

The advantage of using LCA as a decision-aiding tool is its ability to highlight the potential impacts of a product system on a holistic basis. In order to realise this, all potentially significant sources of impact need to be identified at the scoping stage, recorded at the life cycle inventory stage and characterised at the life impact assessment stage. The processing and use of TENORM such as bauxite residue and coal ash as secondary raw materials necessitates the development of a suitable accounting method for the radiological impact of NORM. The framework set out here moves us an important step closer to achieving this aim.

\begin{abstract}
Acknowledgements The research leading to these results has received funding from the European Community's Horizon 2020 Programme ([H2020/2014-2019]) under Grant Agreement no. 636876 (MSCAETN REDMUD). This publication reflects only the authors' view, exempting the Community from any liability. Project website: http://www.etn.redmud.org
\end{abstract}

Open Access This article is distributed under the terms of the Creative Commons Attribution 4.0 International License (http:// creativecommons.org/licenses/by/4.0/), which permits unrestricted use, distribution, and reproduction in any medium, provided you give appropriate credit to the original author(s) and the source, provide a link to the Creative Commons license, and indicate if changes were made.

\section{References}

Ahmari S, Zhang L (2012) Production of eco-friendly bricks from copper mine tailings through geopolymerization. Constr Build Mater 29: 323-331

Andersson P, Beaugelin-Seiller K, Beresford NA et al. (2008) PROTECT-Protection of the Environment from Ionising Radiation in a Regulatory Context-Deliverable 5-Numerical benchmarks for protecting biota from radiation in the environment: proposed levels, underlying reasoning and recommendations

Batayneh M, Marie I, Asi I (2007) Use of selected waste materials in concrete mixes. Waste Manag 27:1870-1876

Brown JE, Alfonso B, Avila R et al (2008) The ERICA tool. J Environ Radioact 99:1371-1383

Chen Y, Zhang Y, Chen T et al (2011) Preparation of eco-friendly construction bricks from hematite tailings. Constr Build Mater 25: 2107-2111

Copplestone D, Hingston J, Real A (2008) The development and purpose of the FREDERICA radiation effects database. J Environ Radioact 99:1456-1463

Cucurachi S, Heijungs R, Peijnenburg WJGM et al (2014) A framework for deciding on the inclusion of emerging impacts in life cycle impact assessment. J Clean Prod 78:152-163

Doka G (2009) Life Cycle Inventories of Waste Treatment Services. Ecoinvent report No. 13. Swiss Centre for Life Cycle Inventories, Dübendorf

Doka G, Hischier R (2005) Waste treatment and assessment of long-term emissions. Int J Life Cycle Assess 10:77-84

Dreicer M, Tort V, Manen P (1995) Externalities of fuel cycles. European Commission, DG XII, Science, Research and Development, JOULE, ExternE Externalities of Energy, Vol. 5, Nuclear

Ecoinvent (2015a) Market for clay brick. GLO, Allocation, default, ecoinvent database version 3:2

Ecoinvent (2015b) Market for sand-lime brick. GLO, Allocation, default, ecoinvent database version 3:2

Ecoinvent (2015c) Market for concrete block. GLO, Allocation, default, ecoinvent database version 3:2

European Commission (2010) Joint Research Centre-Institute for Environment and Sustainability: international reference life cycle data system (ILCD) Handbook - framework and requirements for life cycle impact assessment models and indicators. First edit. Publications Office of the European Union, Luxembourg

European Commission (2011) Joint Research Centre-Institute for Environment and Sustainability: international reference life cycle data system (ILCD) handbook - recommendations for life cycle impact assessment in the European context. First edit. Publications Office of the European Union, Luxembourg

European Union (2014) Council Directive 2013/59/EURATOM of 5 December 2013 laying down basic safety standards for protection against the dangers arising from exposure to ionising radiation, and repealing Directives 89/618/Euratom, 90/641/Euratom, 96/29/ Euratom, 97/43/Euratom. [2014] OJ L13/1

Frederica (2007) FREDERICA database

Frischknecht R, Braunschweig A (2000) Human health damages due to ionising radiation in life cycle impact assessment. Environ Impact Assess Rev 20:159-189

Garnier-Laplace J, Beaugelin-Seiller K, Gilbin R et al (2009) A screening level ecological risk assessment and ranking method for liquid radioactive and chemical mixtures released by nuclear facilities under normal operating conditions. Radioprotection 44:903-908

Goedkoop M, Hofstetter P, Muller-Wenk R, Spriemsma R (1998) The Eco-Indicator 98 explained. Int J Life Cycle Assess 3:352-360

Goedkoop MJ, Heijungs R, Huijbregts M et al (2009) ReCiPe 2008, a life cycle impact assessment method which comprises harmonised 
category indicators at the midpoint and the endpoint level, First edn. Report I, Characterisation

Hauschild MZ, Goedkoop M, Guinée J et al (2013) Identifying best existing practice for characterization modeling in life cycle impact assessment. Int J Life Cycle Assess 18:683-697

Hellweg S, Demou E, Scheringer M et al (2005) Confronting workplace exposure to chemicals with LCA: examples of trichloroethylene and perchlorpethylene in metal degreasing and dry cleaning. Environ Sci Technol 39:7741-7748

Hellweg S, Demou E, Bruzzi R et al (2009) Integrating human indoor air pollutant exposure within life cycle impact assessment. Environ Sci Technol 43:1670-1679

HM Government (2013) Approved Document A-the building regulations 2010. NBS, Newcastle Upon Tyne

Hofstetter P, Norris GA (2003) Why and how should we assess occupational health impacts in integrated product policy? Environ Sci Technol 37:2025-2035

Holdgate MW (1980) A perspective of environmental pollution. CUP Archive

IAEA (1976) Effects of ionising radiation on aquatic organisms and ecosystems

IAEA (2001) Generic models for use in assessing the impact of discharges of radioactive substances to the environment. Safety Reports Series No 19

IAEA (2007) Report of the NORM Working Group of EMRAS Theme 3: modelling the transfer of radionuclides from naturally occurring radioactive material (NORM)

IAEA (2010) Handbook of parameter values for the prediction of radionuclide transfer in terrestrial and freshwater, Technical Reports Series 472. October 1-196

ICRP (1977) Recommendations of the ICRP. ICRP Publication 26. Ann ICRP 1:2-3

ICRP (2007) The 2007 recommendations of the International Commission on Radiological Protection. ICRP Publication 103. Ann ICRP 37:1-332

ICRP (2008) Environmental protection: the concept and use of reference animals and plants. ICRP Publication 108. Ann ICRP 38:1-242

ICRP (2012) Compendium of dose coefficients based on ICRP Publication 60. ICRP Publication 119. Ann ICRP 41(Suppl.:1130). doi:10.1016/j.icrp.2006.06.001

Kikuchi Y, Hirao M (2010) Local risks and global impacts considering plant-specific functions and constraints: a case study of metal parts cleaning. Int J Life Cycle Assess 15:17-31

Koblinger L (1984) Mathematical models of external gamma radiation and congruence of measurements. Radiat Prot Dosim 7:227-234

Aluminium Leader (2015) All about aluminium. http://www. aluminiumleader.com/en/facts/extraction/. Accessed 7 Jul 2015

Quintessa Ltd. (2014) AMBER

Markkanen M (1995) Radiation dose assessments for materials with elevated natural radioactivity

McLeod D (1998) Production of red mud building materials in Jamaica: Case study 1: production of cement stabilized red mud bricks.

Meijer A, Huijbregts M, Reijnders L (2005a) Human health damages due to indoor sources of organic compounds and radioactivity in life cycle impact assessment of dwellings - part 1: characterisation factors. Int J Life Cycle Assess 10:309-316

Meijer A, Huijbregts M, Reijnders L (2005b) Human health damages due to indoor sources of organic compounds and radioactivity in life cycle impact assessment of dwellings - part 2: damage scores. Int J Life Cycle Assess 10:383-392

MSCA-ETN REDMUD (2015) Red Mud Project http://redmud.org/. Accessed 27 Apr 2015

Nuccetelli C, Pontikes Y, Leonardi F, Trevisi R (2015) New perspectives and issues arising from the introduction of (NORM) residues in building materials: a critical assessment on the radiological behaviour. Constr Build Mater 82:323-331

O'Connor BH, Donoghue AM, Manning TJH, Chesson BJ (2013) Radiological assessment for bauxite mining and alumina refining. Ann Occup Hyg 57:63-76

Raut SP, Ralegaonkar RV, Mandavgane SA (2011) Development of sustainable construction material using industrial and agricultural solid waste: a review of waste-create bricks. Constr Build Mater 25:4037-4042

Risica S, Bolzan C, Nuccetelli C (2001) Radioactivity in building materials: room model analysis and experimental methods. Sci Total Environ 272:119-126

Rosenbaum RK, Margni M, Jolliet O (2007) A flexible matrix algebra framework for the multimedia multipathway modeling of emission to impacts. Environ Int 33:624-634

Rosenbaum RK, Bachmann TM, Gold LS et al (2008) USEtox - the UNEP-SETAC toxicity model: recommended characterisation factors for human toxicity and freshwater ecotoxicity in life cycle impact assessment. Int J Life Cycle Assess 13:532-546

Sustainability P (2014) SimaPro:8

Thinkstep (2014) GaBi:6

Trevisi R, Risica S, D'Alessandro M et al (2012) Natural radioactivity in building materials in the European Union: a database and an estimate of radiological significance. J Environ Radioact 105:11-20

UNSCEAR (2000) Sources and effects of ionizing radiation

UNSCEAR (2008) Sources and effects of ionizing radiation

Van Jaarsveld JGS, Van Deventer JSJ, Lorenzen L (1997) The potential use of geopolymeric materials to immobilise toxic metals: part I. Theory and applications. Miner Eng 10:659-669

Walser T, Juraske R, Demou E, Hellweg S (2014) Indoor exposure to toluene from printed matter matters: complementary views from life cycle assessment and risk assessment indoor exposure to toluene from printed matter matters: complementary views from life cycle assessment and risk assessment. Environ Sci Technol 48:689-697

Wenzel H, Hauschild MZ, Alting L (2000) Environmental assessment of products: volume 1: methodology, tools and case studies in product development. Springer Science \& Business Media

World Energy Council (2016) Energy efficiency indicators: average electricity consumption per electrified household. https://www.wecindicators.enerdata.eu/household-electricity-use.html. Accessed 19 Jul 2016

World Nuclear Association (2014) Naturally-occurring radioactive materials (NORM) information paper http://www.world-nuclear. org/info/Safety-and-Security/Radiation-and-Health/NaturallyOccurring-Radioactive-Materials-NORM/. Accessed 27 Apr 2015 